NASA/TM-2000-210322

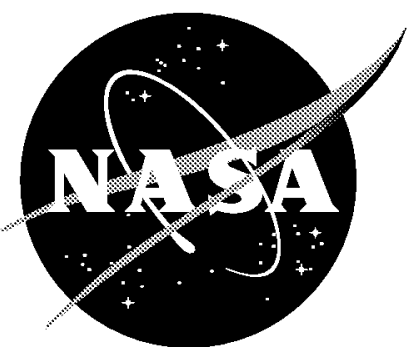

\title{
A 3-D Coupled CFD-DSMC Solution Method With Application to the Mars Sample Return Orbiter
}

Christopher E. Glass and Peter A. Gnoffo

Langley Research Center, Hampton, Virginia 
NASA/TM-2000-210322

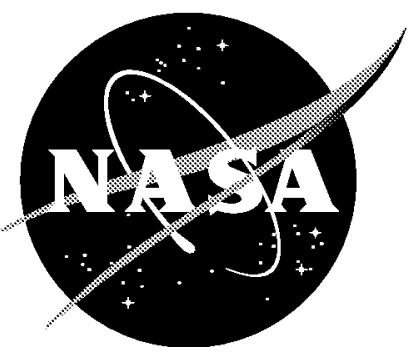

\section{A 3-D Coupled CFD-DSMC Solution Method With Application to the Mars Sample Return Orbiter}

Christopher E. Glass and Peter A. Gnoffo

Langley Research Center, Hampton, Virginia 


\section{The NASA STI Program Office ... in Profile}

Since its founding, NASA has been dedicated to the advancement of aeronautics and space science. The NASA Scientific and Technical Information (STI) Program Office plays a key part in helping NASA maintain this important role.

The NASA STI Program Office is operated by Langley Research Center, the lead center for NASA's scientific and technical information. The NASA STI Program Office provides access to the NASA STI Database, the largest collection of aeronautical and space science STI in the world. The Program Office is also NASA's institutional mechanism for disseminating the results of its research and development activities. These results are published by NASA in the NASA STI Report Series, which includes the following report types:

- TECHNICAL PUBLICATION. Reports of completed research or a major significant phase of research that present the results of NASA programs and include extensive data or theoretical analysis. Includes compilations of significant scientific and technical data and information deemed to be of continuing reference value. NASA counterpart of peer-reviewed formal professional papers, but having less stringent limitations on manuscript length and extent of graphic presentations.

- TECHNICAL MEMORANDUM. Scientific and technical findings that are preliminary or of specialized interest, e.g., quick release reports, working papers, and bibliographies that contain minimal annotation. Does not contain extensive analysis.

- CONTRACTOR REPORT. Scientific and technical findings by NASA-sponsored contractors and grantees.
- CONFERENCE PUBLICATION. Collected papers from scientific and technical conferences, symposia, seminars, or other meetings sponsored or co-sponsored by NASA.

- SPECIAL PUBLICATION. Scientific, technical, or historical information from NASA programs, projects, and missions, often concerned with subjects having substantial public interest.

- TECHNICAL TRANSLATION. Englishlanguage translations of foreign scientific and technical material pertinent to NASA's mission.

Specialized services that complement the STI Program Office's diverse offerings include creating custom thesauri, building customized databases, organizing and publishing research results ... even providing videos.

For more information about the NASA STI Program Office, see the following:

- Access the NASA STI Program Home Page at http://www.sti.nasa.gov

- E-mail your question via the Internet to help@sti.nasa.gov

- Fax your question to the NASA STI Help Desk at (301) 621-0134

- Phone the NASA STI Help Desk at (301) 621-0390

- Write to: NASA STI Help Desk NASA Center for AeroSpace Information 7121 Standard Drive Hanover, MD 21076-1320 


\section{The NASA STI Program Office ... in Profile}

Since its founding, NASA has been dedicated to the advancement of aeronautics and space science. The NASA Scientific and Technical Information (STI) Program Office plays a key part in helping NASA maintain this important role.

The NASA STI Program Office is operated by Langley Research Center, the lead center for NASA's scientific and technical information. The NASA STI Program Office provides access to the NASA STI Database, the largest collection of aeronautical and space science STI in the world. The Program Office is also NASA's institutional mechanism for disseminating the results of its research and development activities. These results are published by NASA in the NASA STI Report Series, which includes the following report types:

- TECHNICAL PUBLICATION. Reports of completed research or a major significant phase of research that present the results of NASA programs and include extensive data or theoretical analysis. Includes compilations of significant scientific and technical data and information deemed to be of continuing reference value. NASA counterpart of peer-reviewed formal professional papers, but having less stringent limitations on manuscript length and extent of graphic presentations.

- TECHNICAL MEMORANDUM. Scientific and technical findings that are preliminary or of specialized interest, e.g., quick release reports, working papers, and bibliographies that contain minimal annotation. Does not contain extensive analysis.

- CONTRACTOR REPORT. Scientific and technical findings by NASA-sponsored contractors and grantees.
- CONFERENCE PUBLICATION. Collected papers from scientific and technical conferences, symposia, seminars, or other meetings sponsored or co-sponsored by NASA.

- SPECIAL PUBLICATION. Scientific, technical, or historical information from NASA programs, projects, and missions, often concerned with subjects having substantial public interest.

- TECHNICAL TRANSLATION. Englishlanguage translations of foreign scientific and technical material pertinent to NASA's mission.

Specialized services that complement the STI Program Office's diverse offerings include creating custom thesauri, building customized databases, organizing and publishing research results ... even providing videos.

For more information about the NASA STI Program Office, see the following:

- Access the NASA STI Program Home Page at http://www.sti.nasa.gov

- E-mail your question via the Internet to help@sti.nasa.gov

- Fax your question to the NASA STI Help Desk at (301) 621-0134

- Phone the NASA STI Help Desk at (301) 621-0390

- Write to: NASA STI Help Desk NASA Center for AeroSpace Information 7121 Standard Drive Hanover, MD 21076-1320 
NASA/TM-2000-210322

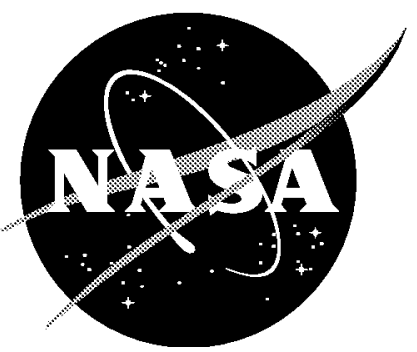

\section{A 3-D Coupled CFD-DSMC Solution Method With Application to the Mars Sample Return Orbiter}

Christopher E. Glass and Peter A. Gnoffo

Langley Research Center, Hampton, Virginia

National Aeronautics and

Space Administration

Langley Research Center

Hampton, Virginia 23681-2199 
NASA/TM-2000-210322

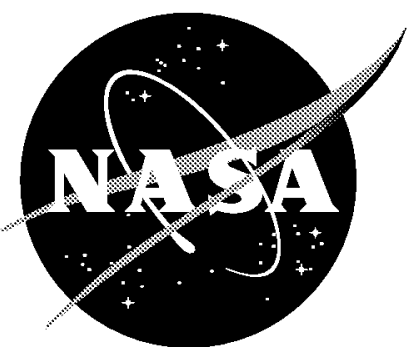

\section{A 3-D Coupled CFD-DSMC Solution Method With Application to the Mars Sample Return Orbiter}

Christopher E. Glass and Peter A. Gnoffo

Langley Research Center, Hampton, Virginia

National Aeronautics and

Space Administration

Langley Research Center

Hampton, Virginia 23681-2199 
Available from:

NASA Center for AeroSpace Information (CASI)

7121 Standard Drive

Hanover, MD 21076-1320

(301) 621-0390
National Technical Information Service (NTIS) 5285 Port Royal Road

Springfield, VA 22161-2171

(703) 605-6000 
Available from:

NASA Center for AeroSpace Information (CASI)

7121 Standard Drive

Hanover, MD 21076-1320

(301) 621-0390
National Technical Information Service (NTIS) 5285 Port Royal Road

Springfield, VA 22161-2171

(703) 605-6000 


\title{
A 3-D Coupled CFD-DSMC Solution Method With Application To The Mars Sample Return Orbiter
}

\author{
Christopher E. Glass and Peter A. Gnoffo \\ Aerothermodynamics Branch, NASA LaRC, Hampton, VA, USA, 23681-2199
}

\begin{abstract}
A method to obtain coupled CFD-DSMC, 3-D flow field solutions for highly blunt bodies at low incidence is presented and applied to one concept of the Mars Sample Return Orbiter vehicle as a demonstration of the technique. CFD is used to solve the high-density blunt forebody flow defining an inflow boundary condition for a DSMC solution of the afterbody wake flow. By combining the two techniques in flow regions where most applicable, the entire mixed flow field is modeled in an appropriate manner.
\end{abstract}

\section{INTRODUCTION}

Different computational methods are needed to determine the aerodynamic and aerothermodynamic characteristics along the entire flight trajectory for aerospace vehicles ascending to orbit or descending through an atmosphere to a planet's surface. Predictions at high altitudes corresponding to the rarefied flow regime are usually accomplished using probabilistic methods such as direct simulation Monte Carlo (DSMC) [1], and predictions at lower altitudes corresponding to the continuum regime use deterministic methods such as computational fluid dynamics (CFD) [2]. However, in a mixed transitional flow regime with rarefied and continuum conditions, such as blunt body wakes, sharp leading edges, and expanding reaction control system plumes, a combination of both techniques can provide a predictive method that exploits the advantages of each technique in its suitable flow domain.

This study presents an approach that is applied to a vehicle encountering mixed transitional and continuum flow, namely the Mars Sample Return Orbiter (MSRO), which is part of the Mars Sample Return project. The project's mission is to return surface material from Mars back to Earth. The MSRO vehicle has as its payload the Earth Entry Vehicle (EEV) and the associated sample material transfer hardware. To be placed into Mars orbit, the MSRO vehicle is to perform a controlled, single-pass aerocapture maneuver in the Martian atmosphere; thus, the vehicle or portions of the vehicle are subjected to flow in the transitional regime at various times during the aerocapture portion of the trajectory. One MSRO vehicle concept consists of an Aeroassist Flight Experiment (AFE) [3] type aeroshell forebody with the payload located behind the aeroshell. Ideally, the payload is contained within the vehicle wake, which minimizes payload exposure to contamination and large aerodynamic and aerothermodynamic loads. However, numerical studies are needed to quantify the wake flow and confirm whether shear layer impingement occurs and adequate protection is provided.

To quantify blunt body wake flow, a recent report of the AGARD Fluid Dynamics Panel Working Group 18 (WG 18) activity of computational and experimental hypersonic blunt body flows was published [4], which outlines activities supported to both define the physics of such flows and provide the results to apply to the design of future planetary vehicles. The blunt body configuration employed was an axisymmetric, 70-deg blunted cone with a circular shoulder blended into an aft flat section normal to the flow direction $\left(\alpha=0^{\circ}\right)$. The flat aft section is attached to a sting section for tunnel support and to provide basic understanding of the wake closure location of the various test points. When subjected to a hypersonic flow, the configuration yields a flow field that is compressed by the forebody and expands rapidly about the shoulder forming a wake region, which closes on the sting.

Various comparisons for the blunted cone configuration have been made; for example, Navier-Stokes and DSMC results of Mach 20, low density wind tunnel condition are presented and compared in [5] and experimental and Navier-Stokes results of Mach 10, low density air are presented and compared in [6]. The primary goal of [6] was 


\title{
A 3-D Coupled CFD-DSMC Solution Method With Application To The Mars Sample Return Orbiter
}

\author{
Christopher E. Glass and Peter A. Gnoffo \\ Aerothermodynamics Branch, NASA LaRC, Hampton, VA, USA, 23681-2199
}

\begin{abstract}
A method to obtain coupled CFD-DSMC, 3-D flow field solutions for highly blunt bodies at low incidence is presented and applied to one concept of the Mars Sample Return Orbiter vehicle as a demonstration of the technique. CFD is used to solve the high-density blunt forebody flow defining an inflow boundary condition for a DSMC solution of the afterbody wake flow. By combining the two techniques in flow regions where most applicable, the entire mixed flow field is modeled in an appropriate manner.
\end{abstract}

\section{INTRODUCTION}

Different computational methods are needed to determine the aerodynamic and aerothermodynamic characteristics along the entire flight trajectory for aerospace vehicles ascending to orbit or descending through an atmosphere to a planet's surface. Predictions at high altitudes corresponding to the rarefied flow regime are usually accomplished using probabilistic methods such as direct simulation Monte Carlo (DSMC) [1], and predictions at lower altitudes corresponding to the continuum regime use deterministic methods such as computational fluid dynamics (CFD) [2]. However, in a mixed transitional flow regime with rarefied and continuum conditions, such as blunt body wakes, sharp leading edges, and expanding reaction control system plumes, a combination of both techniques can provide a predictive method that exploits the advantages of each technique in its suitable flow domain.

This study presents an approach that is applied to a vehicle encountering mixed transitional and continuum flow, namely the Mars Sample Return Orbiter (MSRO), which is part of the Mars Sample Return project. The project's mission is to return surface material from Mars back to Earth. The MSRO vehicle has as its payload the Earth Entry Vehicle (EEV) and the associated sample material transfer hardware. To be placed into Mars orbit, the MSRO vehicle is to perform a controlled, single-pass aerocapture maneuver in the Martian atmosphere; thus, the vehicle or portions of the vehicle are subjected to flow in the transitional regime at various times during the aerocapture portion of the trajectory. One MSRO vehicle concept consists of an Aeroassist Flight Experiment (AFE) [3] type aeroshell forebody with the payload located behind the aeroshell. Ideally, the payload is contained within the vehicle wake, which minimizes payload exposure to contamination and large aerodynamic and aerothermodynamic loads. However, numerical studies are needed to quantify the wake flow and confirm whether shear layer impingement occurs and adequate protection is provided.

To quantify blunt body wake flow, a recent report of the AGARD Fluid Dynamics Panel Working Group 18 (WG 18) activity of computational and experimental hypersonic blunt body flows was published [4], which outlines activities supported to both define the physics of such flows and provide the results to apply to the design of future planetary vehicles. The blunt body configuration employed was an axisymmetric, 70-deg blunted cone with a circular shoulder blended into an aft flat section normal to the flow direction $\left(\alpha=0^{\circ}\right)$. The flat aft section is attached to a sting section for tunnel support and to provide basic understanding of the wake closure location of the various test points. When subjected to a hypersonic flow, the configuration yields a flow field that is compressed by the forebody and expands rapidly about the shoulder forming a wake region, which closes on the sting.

Various comparisons for the blunted cone configuration have been made; for example, Navier-Stokes and DSMC results of Mach 20, low density wind tunnel condition are presented and compared in [5] and experimental and Navier-Stokes results of Mach 10, low density air are presented and compared in [6]. The primary goal of [6] was 
an axisymmetric study, but during the Mach 10 experiment angle-of-attack, $\alpha$, of the blunt body was varied $\pm 20^{\circ}$ to yield forebody and afterbody (sting) heating. As the angle of attack was changed, windside sting heating increased by over a factor of 2 and the location of maximum heating moved upstream towards the blunt body base [6]. Several other important conclusions of the WG 18 activity [4] are that the Navier-Stokes solutions of the wake region match those of the DSMC for Knudsen number based on the free stream conditions and appropriate body length (forebody diameter), $\mathrm{Kn}_{\mathrm{L}}$, less than a value of about 0.001 ; that functional relationships exist between the flow rarefaction $\left(\mathrm{Kn}_{\mathrm{L}}\right)$ and the strength of the wake vortical flow; and the locations on the afterbody (sting) of free shear layer impingement and of maximum heating are not the same (These results are also shown in [5].).

The basic features of the flow field and surface produced by the axisymmetric configuration (i.e., blunt body flow compression, rapid expansion of a thermally excited, non-equilibrium flow to a rarefied condition, closure of the wake by shear layer convergence, and differences on the afterbody in shear layer impingement and maximum) should be qualitatively similar to those of the MRSO during its Mars aerocapture trajectory. However, to provide quantitative flight results for a three-dimensional configuration such as the MSRO, a numerical computation using the most reliable predictive methods is needed. The flow field and corresponding surface pressure and heating distributions for the axisymmetric case can then be employed to provide a qualitative comparison or a so called "sanity check" of features of the full three-dimensional configuration.

\section{SOLUTION METHODOLOGY}

A combination of rarefied and continuum methods is needed to properly analyze flow fields having continuum, transitional, and rarefied regions. The physical nature of the flow field dictates the proper treatment of the boundary between the continuum and rarefied portions. For example, solution methods for unsteady flow containing both continuum and rarefied regions must strongly couple the two so that information can be transferred between them [7]. The boundary for this case must track temporal and spatial fluctuations between the regions. However, for an assumed steady flow field solution with a region of continuum fluid expanding into a rarefied region, such as shown in the studies presented in [8-10], the continuum region is obtained with CFD, which in turn provides an inflow boundary for a DSMC solution domain. By combining the continuum and non-continuum solutions, flow fields with order of magnitude changes in density from continuum to rarefied flow can be obtained without the complexity of strong coupling, but with the advantage of using the best method in each region.

Comparisons between fully coupled and zonally decoupled solutions of forebody and afterbody flow about an axisymmetric blunt body are presented in [10]. The fully coupled solution consisted of an overlap region between the CFD and DSMC portions of the flow to account for the non-equilibrium condition of the flow as it expands about the forebody to the wake region. The zonally decoupled solution used the equilibrium temperature of the CFD as the inflow DSMC overall temperature. Results from [10] show that the zonally decoupled solutions adequately defined the wake flow when compared to the coupled solutions. In addition, for the conditions of [10], no significant difference in the mean-flow wake properties were produced by not including the non-equilibrium effects at the CFD-DSMC interface. Therefore, an approach similar to the zonally decoupled method of [10] is employed for the present study.

The current approach for 3-D flow field modeling of the MSRO is to apply the continuum analysis of CFD using the Langley Aerothermodynamic Upwind Relaxation Algorithm (LAURA) code [11] to the high-density blunt forebody flow field region of the aeroshell and the molecular analysis of DSMC using the DSMC analysis code (DAC) [12] to the afterbody wake flow field. Shown in Fig. 1 is a side view of the MSRO configuration with the interface between the CFD and DSMC portions of the flow field shown as the solid line dividing the regions at the aeroshell lip. The cavity behind the forebody aeroshell shown in the figure, which forms a bowl-like shape with flow reversing direction if it follows the inner shell geometry, is contained in the DSMC portion of the solution domain. The planar CFD flow field variables at the interface provide an inflow boundary condition for the DSMC wake flow field simulation. A planar surface was chosen to divide the two computational regions to primarily capture the expanding flow about the aeroshell lip as the sharp-edged lip between the forebody and afterbody provides a natural transition between continuum and rarefied treated regions, and secondarily because of ease of setup and implementation of the scheme.

In addition, to model the wake flow field about a 3-D configuration with a near continuum free stream condition $\left(\mathrm{Kn}_{\mathrm{L}} \approx 0.001\right)$, a DSMC computation that includes a fully adapted grid behind the plane at the aeroshell lip would require an exorbitant number of simulated molecules and be too costly in both computational resources 
an axisymmetric study, but during the Mach 10 experiment angle-of-attack, $\alpha$, of the blunt body was varied $\pm 20^{\circ}$ to yield forebody and afterbody (sting) heating. As the angle of attack was changed, windside sting heating increased by over a factor of 2 and the location of maximum heating moved upstream towards the blunt body base [6]. Several other important conclusions of the WG 18 activity [4] are that the Navier-Stokes solutions of the wake region match those of the DSMC for Knudsen number based on the free stream conditions and appropriate body length (forebody diameter), $\mathrm{Kn}_{\mathrm{L}}$, less than a value of about 0.001 ; that functional relationships exist between the flow rarefaction $\left(\mathrm{Kn}_{\mathrm{L}}\right)$ and the strength of the wake vortical flow; and the locations on the afterbody (sting) of free shear layer impingement and of maximum heating are not the same (These results are also shown in [5].).

The basic features of the flow field and surface produced by the axisymmetric configuration (i.e., blunt body flow compression, rapid expansion of a thermally excited, non-equilibrium flow to a rarefied condition, closure of the wake by shear layer convergence, and differences on the afterbody in shear layer impingement and maximum) should be qualitatively similar to those of the MRSO during its Mars aerocapture trajectory. However, to provide quantitative flight results for a three-dimensional configuration such as the MSRO, a numerical computation using the most reliable predictive methods is needed. The flow field and corresponding surface pressure and heating distributions for the axisymmetric case can then be employed to provide a qualitative comparison or a so called "sanity check" of features of the full three-dimensional configuration.

\section{SOLUTION METHODOLOGY}

A combination of rarefied and continuum methods is needed to properly analyze flow fields having continuum, transitional, and rarefied regions. The physical nature of the flow field dictates the proper treatment of the boundary between the continuum and rarefied portions. For example, solution methods for unsteady flow containing both continuum and rarefied regions must strongly couple the two so that information can be transferred between them [7]. The boundary for this case must track temporal and spatial fluctuations between the regions. However, for an assumed steady flow field solution with a region of continuum fluid expanding into a rarefied region, such as shown in the studies presented in [8-10], the continuum region is obtained with CFD, which in turn provides an inflow boundary for a DSMC solution domain. By combining the continuum and non-continuum solutions, flow fields with order of magnitude changes in density from continuum to rarefied flow can be obtained without the complexity of strong coupling, but with the advantage of using the best method in each region.

Comparisons between fully coupled and zonally decoupled solutions of forebody and afterbody flow about an axisymmetric blunt body are presented in [10]. The fully coupled solution consisted of an overlap region between the CFD and DSMC portions of the flow to account for the non-equilibrium condition of the flow as it expands about the forebody to the wake region. The zonally decoupled solution used the equilibrium temperature of the CFD as the inflow DSMC overall temperature. Results from [10] show that the zonally decoupled solutions adequately defined the wake flow when compared to the coupled solutions. In addition, for the conditions of [10], no significant difference in the mean-flow wake properties were produced by not including the non-equilibrium effects at the CFD-DSMC interface. Therefore, an approach similar to the zonally decoupled method of [10] is employed for the present study.

The current approach for 3-D flow field modeling of the MSRO is to apply the continuum analysis of CFD using the Langley Aerothermodynamic Upwind Relaxation Algorithm (LAURA) code [11] to the high-density blunt forebody flow field region of the aeroshell and the molecular analysis of DSMC using the DSMC analysis code (DAC) [12] to the afterbody wake flow field. Shown in Fig. 1 is a side view of the MSRO configuration with the interface between the CFD and DSMC portions of the flow field shown as the solid line dividing the regions at the aeroshell lip. The cavity behind the forebody aeroshell shown in the figure, which forms a bowl-like shape with flow reversing direction if it follows the inner shell geometry, is contained in the DSMC portion of the solution domain. The planar CFD flow field variables at the interface provide an inflow boundary condition for the DSMC wake flow field simulation. A planar surface was chosen to divide the two computational regions to primarily capture the expanding flow about the aeroshell lip as the sharp-edged lip between the forebody and afterbody provides a natural transition between continuum and rarefied treated regions, and secondarily because of ease of setup and implementation of the scheme.

In addition, to model the wake flow field about a 3-D configuration with a near continuum free stream condition $\left(\mathrm{Kn}_{\mathrm{L}} \approx 0.001\right)$, a DSMC computation that includes a fully adapted grid behind the plane at the aeroshell lip would require an exorbitant number of simulated molecules and be too costly in both computational resources 
(memory, cpu's, etc.) and wall time to produce with today's computational resources. Therefore, the concept of a near body adapted grid is presented and employed for the near continuum DSMC cases presented below. To incorporate the near body adapted grid into a solution, a modification was made to the DAC [12] preprocessor. Because the preprocessor adapts level II cells into a level I uniformly distributed grid, the near body adaptation routine was easily implemented by limiting level I cell adaptation to those closest to the body.

As discussed above, CFD for the forebody was performed by the LAURA code. The Mars atmosphere was modeled as an eight specie, non-equilibrium gas. The forebody temperature was held constant at $1500 \mathrm{~K}$ and the wall was assumed fully catalytic. All DSMC simulations performed by the DAC code include translational, rotational, and vibrational contributions employing a nine specie model of the Mars atmosphere for which argon was ignored to match LAURA chemistry. The MSRO surface is assumed fully diffuse, non-catalytic, and constant temperature. For the two higher $\mathrm{Kn}_{\mathrm{L}}$ cases the wall temperature was fixed at $300 \mathrm{~K}$; for the two lower $\mathrm{Kn}_{\mathrm{L}}$ cases, the wall temperature was 500K. Additionally, the nearest neighbor collision algorithm of DAC, which selects closest molecules that are normal to the surface as most probable collision partners and provides virtual cell enhancement, was employed. The algorithm reduces the need for wall cells to be sized on the order of the local mean free path.

\section{RESULTS AND DISCUSSION}

Given in this section are simulation results that correspond to various altitudes in the $\mathrm{CO}_{2}-\mathrm{N}_{2}$ Mars atmosphere at times near the start of the aerocapture maneuver of a proposed MSRO mission. Cases at four altitudes are considered with $\mathrm{Kn}_{\mathrm{L}}=0.2,0.02,0.002,0.0004$. (Note that the free stream mean free path, $\lambda_{\infty}$, calculated using the hard sphere model, and the maximum body length of the aeroshell, L, of $3.65 \mathrm{~m}$, shown in Fig. 2, are used to determine $\mathrm{Kn}_{\mathrm{L}}$.) Emphasis will be placed on two cases: $\mathrm{Kn}_{\mathrm{L}}=0.02$ and $\mathrm{Kn}_{\mathrm{L}}=0.002$, which are in the transitional regime between continuum and rarefied. The two most rarefied cases are computed with DSMC only. For $\mathrm{Kn}_{\mathrm{L}}=0.02$, solutions from a near body adapted grid and a fully adapted grid solution are presented to assess the viability of only employing finely spaced grid near the body. Then, DSMC is applied to the body adapted grid to produce solutions for the $\mathrm{Kn}_{\mathrm{L}}=0.002$ and 0.0004 cases, which use the CFD forebody inflow boundary solution. Finally, some noteworthy surface results on the afterbody as a function of $\mathrm{Kn}_{\mathrm{L}}$ are presented and discussed to summarize the study.

A side view of the MSRO configuration is shown in Fig. 1. All results given in the present study are for the configuration at angle-of-attack, $\alpha$, of $-4^{\circ}$. All solutions are presented so that the free stream velocity vector is horizontal as shown in Fig. 1. Note that the negative angle-of-attack rotates the flow toward the upper cylindrical afterbody portion of the configuration. Surface pressure and heating along the upper cylindrical surface, which are given subsequently, are presented as a function of $\mathrm{s} / \mathrm{l}$ as shown in Fig. 2 . In addition, when presented, wake flow properties are taken at either one of the two downstream stations $(X=3 \mathrm{~m}$ and $X=6 \mathrm{~m}$ ) from the MSRO (See Fig. 2.).

The computational size of a 3-D simulation of a blunt body wake flow with $\mathrm{Kn}_{\mathrm{L}} \approx 0.001$ can be reasonably reduced if fine grid adaptation is confined to the region near the configuration surface. It is supposed that by capturing only near body gradients with sufficient grid resolution the simulation will not be sufficiently degraded. To this end, two simulations were performed at the $\mathrm{Kn}_{\mathrm{L}}=0.02$ fight condition for DSMC only. The $\mathrm{Kn}_{\mathrm{L}}=0.02$ flow condition simulations were on a configuration with the only difference being the grid. Therefore, a fully adapted and a near body adapted grid were obtained from the same initial grid; The symmetry plane from each is shown in Figs. 3 and 4, respectively. DSMC using the DAC code was applied to the two grids and the number of simulated molecules was reduced by over one-third with the near body grid. Although forebody region grid reduction is included, a comparison of the two grids does show that by not finely gridding the bow shock wave past the 3-D configuration, a reduction of the number of cells is still realized.

Results of the DSMC computations on the upper cylinder surface are shown in Fig. 5. The $\mathrm{C}_{\mathrm{p}}$ and $\mathrm{C}_{\mathrm{H}}$ values rise from the root region to the cylinder end at $\mathrm{s} / \mathrm{l}=1$ with the same general shape. (The pressure coefficient is $\mathrm{C}_{\mathrm{p}}=\left(\mathrm{p}-\mathrm{p}_{\infty}\right) / 1 / 2 \rho_{\infty} \mathrm{V}_{\infty}{ }^{2}$ and the heat transfer coefficient is $\mathrm{C}_{\mathrm{H}}=\mathrm{q} / 1 / 2 \rho_{\infty} \mathrm{V}_{\infty}{ }^{3}$.) For both $\mathrm{C}_{\mathrm{p}}$ and $\mathrm{C}_{\mathrm{H}}$, the near body adapted grid yields values that are lower than the fully adapted grid. However, the maximum difference is small: $5 \%$ difference in $\mathrm{C}_{\mathrm{p}, \max }$ and $3.5 \%$ difference in $\mathrm{C}_{\mathrm{H}, \max }$. Presented in Fig. 6 are the overall temperature profiles at the two $\mathrm{X}$ stations shown in Fig. 2. Generally, the temperature difference between the two simulations at $3 \mathrm{~m}$ and $6 \mathrm{~m}$ stations follow the same trends. At the maximum temperature, the difference is less than $50 \mathrm{~K}$ (about $1 \%$ ). Based on 
(memory, cpu's, etc.) and wall time to produce with today's computational resources. Therefore, the concept of a near body adapted grid is presented and employed for the near continuum DSMC cases presented below. To incorporate the near body adapted grid into a solution, a modification was made to the DAC [12] preprocessor. Because the preprocessor adapts level II cells into a level I uniformly distributed grid, the near body adaptation routine was easily implemented by limiting level I cell adaptation to those closest to the body.

As discussed above, CFD for the forebody was performed by the LAURA code. The Mars atmosphere was modeled as an eight specie, non-equilibrium gas. The forebody temperature was held constant at $1500 \mathrm{~K}$ and the wall was assumed fully catalytic. All DSMC simulations performed by the DAC code include translational, rotational, and vibrational contributions employing a nine specie model of the Mars atmosphere for which argon was ignored to match LAURA chemistry. The MSRO surface is assumed fully diffuse, non-catalytic, and constant temperature. For the two higher $\mathrm{Kn}_{\mathrm{L}}$ cases the wall temperature was fixed at $300 \mathrm{~K}$; for the two lower $\mathrm{Kn}_{\mathrm{L}}$ cases, the wall temperature was 500K. Additionally, the nearest neighbor collision algorithm of DAC, which selects closest molecules that are normal to the surface as most probable collision partners and provides virtual cell enhancement, was employed. The algorithm reduces the need for wall cells to be sized on the order of the local mean free path.

\section{RESULTS AND DISCUSSION}

Given in this section are simulation results that correspond to various altitudes in the $\mathrm{CO}_{2}-\mathrm{N}_{2}$ Mars atmosphere at times near the start of the aerocapture maneuver of a proposed MSRO mission. Cases at four altitudes are considered with $\mathrm{Kn}_{\mathrm{L}}=0.2,0.02,0.002,0.0004$. (Note that the free stream mean free path, $\lambda_{\infty}$, calculated using the hard sphere model, and the maximum body length of the aeroshell, L, of $3.65 \mathrm{~m}$, shown in Fig. 2, are used to determine $\mathrm{Kn}_{\mathrm{L}}$.) Emphasis will be placed on two cases: $\mathrm{Kn}_{\mathrm{L}}=0.02$ and $\mathrm{Kn}_{\mathrm{L}}=0.002$, which are in the transitional regime between continuum and rarefied. The two most rarefied cases are computed with DSMC only. For $\mathrm{Kn}_{\mathrm{L}}=0.02$, solutions from a near body adapted grid and a fully adapted grid solution are presented to assess the viability of only employing finely spaced grid near the body. Then, DSMC is applied to the body adapted grid to produce solutions for the $\mathrm{Kn}_{\mathrm{L}}=0.002$ and 0.0004 cases, which use the CFD forebody inflow boundary solution. Finally, some noteworthy surface results on the afterbody as a function of $\mathrm{Kn}_{\mathrm{L}}$ are presented and discussed to summarize the study.

A side view of the MSRO configuration is shown in Fig. 1. All results given in the present study are for the configuration at angle-of-attack, $\alpha$, of $-4^{\circ}$. All solutions are presented so that the free stream velocity vector is horizontal as shown in Fig. 1. Note that the negative angle-of-attack rotates the flow toward the upper cylindrical afterbody portion of the configuration. Surface pressure and heating along the upper cylindrical surface, which are given subsequently, are presented as a function of $\mathrm{s} / \mathrm{l}$ as shown in Fig. 2 . In addition, when presented, wake flow properties are taken at either one of the two downstream stations $(X=3 \mathrm{~m}$ and $X=6 \mathrm{~m}$ ) from the MSRO (See Fig. 2.).

The computational size of a 3-D simulation of a blunt body wake flow with $\mathrm{Kn}_{\mathrm{L}} \approx 0.001$ can be reasonably reduced if fine grid adaptation is confined to the region near the configuration surface. It is supposed that by capturing only near body gradients with sufficient grid resolution the simulation will not be sufficiently degraded. To this end, two simulations were performed at the $\mathrm{Kn}_{\mathrm{L}}=0.02$ fight condition for DSMC only. The $\mathrm{Kn}_{\mathrm{L}}=0.02$ flow condition simulations were on a configuration with the only difference being the grid. Therefore, a fully adapted and a near body adapted grid were obtained from the same initial grid; The symmetry plane from each is shown in Figs. 3 and 4, respectively. DSMC using the DAC code was applied to the two grids and the number of simulated molecules was reduced by over one-third with the near body grid. Although forebody region grid reduction is included, a comparison of the two grids does show that by not finely gridding the bow shock wave past the 3-D configuration, a reduction of the number of cells is still realized.

Results of the DSMC computations on the upper cylinder surface are shown in Fig. 5. The $\mathrm{C}_{\mathrm{p}}$ and $\mathrm{C}_{\mathrm{H}}$ values rise from the root region to the cylinder end at $\mathrm{s} / \mathrm{l}=1$ with the same general shape. (The pressure coefficient is $\mathrm{C}_{\mathrm{p}}=\left(\mathrm{p}-\mathrm{p}_{\infty}\right) / 1 / 2 \rho_{\infty} \mathrm{V}_{\infty}{ }^{2}$ and the heat transfer coefficient is $\mathrm{C}_{\mathrm{H}}=\mathrm{q} / 1 / 2 \rho_{\infty} \mathrm{V}_{\infty}{ }^{3}$.) For both $\mathrm{C}_{\mathrm{p}}$ and $\mathrm{C}_{\mathrm{H}}$, the near body adapted grid yields values that are lower than the fully adapted grid. However, the maximum difference is small: $5 \%$ difference in $\mathrm{C}_{\mathrm{p}, \max }$ and $3.5 \%$ difference in $\mathrm{C}_{\mathrm{H}, \max }$. Presented in Fig. 6 are the overall temperature profiles at the two $\mathrm{X}$ stations shown in Fig. 2. Generally, the temperature difference between the two simulations at $3 \mathrm{~m}$ and $6 \mathrm{~m}$ stations follow the same trends. At the maximum temperature, the difference is less than $50 \mathrm{~K}$ (about $1 \%$ ). Based on 
the results given in Figs. 5 and 6, it is concluded that for this case, the near body adapted grid solution is sufficiently accurate to define the surface and near wake flow field with considerable reduction in computational resources.

Although the near body grid adaptation scheme is validated for a wake, which is more rarefied, the results give promise that the technique may allow reasonable predictions of flow simulations of less rarefied wake flows. Therefore, the near body grid method is applied to a lower $\mathrm{Kn}_{\mathrm{L}}$ condition. Fig. 7 shows the near body adapted grid at the symmetry plane for the $\mathrm{Kn}_{\mathrm{L}}=0.002$ condition. The fine grid about the body is shown as a gray shading because the cells are so small. The wake density profile given in Fig. 8 shows the variation from the free stream value below the lower bow shock, increasing and decreasing across the shock wave moving upward, then through the low density wake downstream of the MSRO and upper portion of the bow wake, which is captured by the DSMC computation. The combination of the streamlines in the density field and velocity vectors at the $X=3 \mathrm{~m}$ and $6 \mathrm{~m}$ locations show that the flow close to the upper lip travels downward close to the configuration before being swept into the wake. The vectors show a deficit in the velocity below the center of the configuration at the $3 \mathrm{~m}$ station, which persists to the $6 \mathrm{~m}$ station, as a result of the flow about the forebody. Note that there is flow impingement on the upper cylinder surface with a primary and secondary vortex structure produced in the recessed region behind the aeroshell just below and to the left of the flow impingement point.

On the cylinder surface, as shown in Fig. 9, the $C_{p}$ value initially falls slightly from the root value $(s / l=0)$, recovers, and then rises before reaching a maximum prior to the end of the cylinder. However, $\mathrm{C}_{\mathrm{H}}$ monotonically rises from a minimum value at the cylinder root to a maximum at the cylinder end $(\mathrm{s} / \mathrm{l}=1)$. Flow field translational, rotational, and vibrational temperatures in the wake at the $X=6 \mathrm{~m}$ station are given in Fig. 10 for this condition. The temperatures show that all three energy modes modeled by the DSMC are energized; thus, the wake is in a non-equilibrium state. Hence, it is important to properly define the wake flow chemistry for this condition.

Figs. 11 and 12 summarize the flow field effects on the MSRO afterbody cylinder from all cases computed. Surface shear stress was analyzed to define the location of the primary vortex attachment and separation and the location of the secondary vortex near the cylinder root. The analysis of shear stress showed that the flow attachment and separation were at zero valued shear stress with the sign of shear stress defining the local flow direction elsewhere. Although the use of the body grid adaptation scheme for $\mathrm{Kn}_{\mathrm{L}}=0.0004$ has not been established, it was employed, and the results are presented in Fig. 11 to help establish trends.

The triangles shown in Fig. 11 represent the attachment of the primary vortex and of flow expanding about the upper aeroshell lip onto the cylinder as a function of $\mathrm{Kn}_{\mathrm{L}}$. The gradient symbols represent the separation of the primary and secondary (if present) vortices from the surface. Note that the secondary vortex for the $\mathrm{Kn}_{\mathrm{L}}=0.002$ condition is shown in Fig. 8 close to the cylinder root $(\mathrm{s} / \mathrm{l}=0)$ by the small rolled streamline trace. As $\mathrm{Kn}_{\mathrm{L}}$ increases, the attachment moves down the cylinder, the extent of the primary vortex tends to remain the same, but the secondary vortex becomes smaller (Note the location and distance between the flow attachment and separation.) until the secondary vortex disappears for $\mathrm{Kn}_{\mathrm{L}}>0.02$ and the primary vortex size decreases further. As shown on the figure, the effect of increasing $\mathrm{Kn}_{\mathrm{L}}$ on the maximum $\mathrm{C}_{\mathrm{p}}$ and $\mathrm{C}_{\mathrm{H}}$ location is to move that point toward the cylinder end, opposite the direction of flow attachment location. For $\mathrm{Kn}_{\mathrm{L}}>0.002, \mathrm{C}_{\mathrm{H} \text {,max }}$ is at the cylinder end and for $\mathrm{Kn}_{\mathrm{L}}=0.02, \mathrm{C}_{\mathrm{p}, \max }$ is located at the end. These results are similar to those presented for an axisymmetric blunt body [4]; i.e., the size of the wake vortex region increases as $\mathrm{Kn}_{\mathrm{L}}$ decreases and flow attachment does not coincide with maximum $C_{p}$ and $C_{H}$. The values of $C_{p, \text { max }}$ and $C_{H, \text { max }}$ as a function of $\mathrm{Kn}_{\mathrm{L}}$ are given in Fig. 12. (Note the value for the $\mathrm{Kn}_{\mathrm{L}}=0.0004$ condition is not included in the figure because the level II cells near the maxima were not spaced closely enough to provide adequate flow resolution.) The trend of the $C_{p, \max }$ data is that it decreases with increasing $\mathrm{Kn}_{\mathrm{L}}$; Conversely, the trend shown for $\mathrm{C}_{\mathrm{H} \text {,max }}$ is that it increases with increasing $\mathrm{Kn}_{\mathrm{L}}$.

\section{CONCLUSIONS}

Two methods have been developed to reduce the computational demand of producing 3-D DSMC blunt body wake solutions for configurations with flow conditions of $\mathrm{Kn}_{\mathrm{L}} \approx 0.001$ or greater. It has been previously shown that DSMC is required to provide adequate simulation in the wake region for this flow condition. The present study introduces, for the 3-D MSRO configuration, a method that uses a CFD forebody solution as an inflow condition to the DSMC at a planar boundary at the aeroshell lip. In addition, fine grid adaptation is limited to the near body region only to capture with fine grid flow details near the body. Although the results from this study are given as a "work in progress," the methods employed are encouraging in reducing the grid and, hence, the total computational effort to produce these near continuum solutions. Trends presented for the vortical flow near the afterbody cylinder 
the results given in Figs. 5 and 6, it is concluded that for this case, the near body adapted grid solution is sufficiently accurate to define the surface and near wake flow field with considerable reduction in computational resources.

Although the near body grid adaptation scheme is validated for a wake, which is more rarefied, the results give promise that the technique may allow reasonable predictions of flow simulations of less rarefied wake flows. Therefore, the near body grid method is applied to a lower $\mathrm{Kn}_{\mathrm{L}}$ condition. Fig. 7 shows the near body adapted grid at the symmetry plane for the $\mathrm{Kn}_{\mathrm{L}}=0.002$ condition. The fine grid about the body is shown as a gray shading because the cells are so small. The wake density profile given in Fig. 8 shows the variation from the free stream value below the lower bow shock, increasing and decreasing across the shock wave moving upward, then through the low density wake downstream of the MSRO and upper portion of the bow wake, which is captured by the DSMC computation. The combination of the streamlines in the density field and velocity vectors at the $X=3 \mathrm{~m}$ and $6 \mathrm{~m}$ locations show that the flow close to the upper lip travels downward close to the configuration before being swept into the wake. The vectors show a deficit in the velocity below the center of the configuration at the $3 \mathrm{~m}$ station, which persists to the $6 \mathrm{~m}$ station, as a result of the flow about the forebody. Note that there is flow impingement on the upper cylinder surface with a primary and secondary vortex structure produced in the recessed region behind the aeroshell just below and to the left of the flow impingement point.

On the cylinder surface, as shown in Fig. 9, the $C_{p}$ value initially falls slightly from the root value $(s / l=0)$, recovers, and then rises before reaching a maximum prior to the end of the cylinder. However, $\mathrm{C}_{\mathrm{H}}$ monotonically rises from a minimum value at the cylinder root to a maximum at the cylinder end $(\mathrm{s} / \mathrm{l}=1)$. Flow field translational, rotational, and vibrational temperatures in the wake at the $X=6 \mathrm{~m}$ station are given in Fig. 10 for this condition. The temperatures show that all three energy modes modeled by the DSMC are energized; thus, the wake is in a non-equilibrium state. Hence, it is important to properly define the wake flow chemistry for this condition.

Figs. 11 and 12 summarize the flow field effects on the MSRO afterbody cylinder from all cases computed. Surface shear stress was analyzed to define the location of the primary vortex attachment and separation and the location of the secondary vortex near the cylinder root. The analysis of shear stress showed that the flow attachment and separation were at zero valued shear stress with the sign of shear stress defining the local flow direction elsewhere. Although the use of the body grid adaptation scheme for $\mathrm{Kn}_{\mathrm{L}}=0.0004$ has not been established, it was employed, and the results are presented in Fig. 11 to help establish trends.

The triangles shown in Fig. 11 represent the attachment of the primary vortex and of flow expanding about the upper aeroshell lip onto the cylinder as a function of $\mathrm{Kn}_{\mathrm{L}}$. The gradient symbols represent the separation of the primary and secondary (if present) vortices from the surface. Note that the secondary vortex for the $\mathrm{Kn}_{\mathrm{L}}=0.002$ condition is shown in Fig. 8 close to the cylinder root $(\mathrm{s} / \mathrm{l}=0)$ by the small rolled streamline trace. As $\mathrm{Kn}_{\mathrm{L}}$ increases, the attachment moves down the cylinder, the extent of the primary vortex tends to remain the same, but the secondary vortex becomes smaller (Note the location and distance between the flow attachment and separation.) until the secondary vortex disappears for $\mathrm{Kn}_{\mathrm{L}}>0.02$ and the primary vortex size decreases further. As shown on the figure, the effect of increasing $\mathrm{Kn}_{\mathrm{L}}$ on the maximum $\mathrm{C}_{\mathrm{p}}$ and $\mathrm{C}_{\mathrm{H}}$ location is to move that point toward the cylinder end, opposite the direction of flow attachment location. For $\mathrm{Kn}_{\mathrm{L}}>0.002, \mathrm{C}_{\mathrm{H} \text {,max }}$ is at the cylinder end and for $\mathrm{Kn}_{\mathrm{L}}=0.02, \mathrm{C}_{\mathrm{p}, \max }$ is located at the end. These results are similar to those presented for an axisymmetric blunt body [4]; i.e., the size of the wake vortex region increases as $\mathrm{Kn}_{\mathrm{L}}$ decreases and flow attachment does not coincide with maximum $C_{p}$ and $C_{H}$. The values of $C_{p, \text { max }}$ and $C_{H, \text { max }}$ as a function of $\mathrm{Kn}_{\mathrm{L}}$ are given in Fig. 12. (Note the value for the $\mathrm{Kn}_{\mathrm{L}}=0.0004$ condition is not included in the figure because the level II cells near the maxima were not spaced closely enough to provide adequate flow resolution.) The trend of the $C_{p, \max }$ data is that it decreases with increasing $\mathrm{Kn}_{\mathrm{L}}$; Conversely, the trend shown for $\mathrm{C}_{\mathrm{H} \text {,max }}$ is that it increases with increasing $\mathrm{Kn}_{\mathrm{L}}$.

\section{CONCLUSIONS}

Two methods have been developed to reduce the computational demand of producing 3-D DSMC blunt body wake solutions for configurations with flow conditions of $\mathrm{Kn}_{\mathrm{L}} \approx 0.001$ or greater. It has been previously shown that DSMC is required to provide adequate simulation in the wake region for this flow condition. The present study introduces, for the 3-D MSRO configuration, a method that uses a CFD forebody solution as an inflow condition to the DSMC at a planar boundary at the aeroshell lip. In addition, fine grid adaptation is limited to the near body region only to capture with fine grid flow details near the body. Although the results from this study are given as a "work in progress," the methods employed are encouraging in reducing the grid and, hence, the total computational effort to produce these near continuum solutions. Trends presented for the vortical flow near the afterbody cylinder 
are similar to those given previously [4], i.e., the size of the wake vortex region increases as $\mathrm{Kn}_{\mathrm{L}}$ decreases and flow attachment does not coincide with maximum $\mathrm{C}_{\mathrm{p}}$ and $\mathrm{C}_{\mathrm{H}}$, thus giving some credence to the present method. In addition, the results show that in the wake region for the flow conditions of this study, non-equilibrium chemistry is present in the wake behind the blunt body and should be accounted for in the simulation.

\section{ACKNOWLEDGMENTS}

The help provided by Gerald LeBeau of NASA JSC and Richard Wilmoth of NASA LaRC in resolving DAC code issues is acknowledged. James Moss of NASA LaRC provided helpful insight into wake flows of blunt body configurations. Jean Oswald of O.N.E.R.A. is acknowledged for providing the volume grid for CFD and the IGES surface definition of the MSRO. Ramadus Prabhu of Lockheed Martin was instrumental in creating a triangulated surface grid from the IGES format using the GridTool software.

\section{REFERENCES}

1. Bird, G.A., Molecular Gas Dynamics and the Direct Simulation of Gas Flows, Oxford University Press, New York, 1994.

2. Anderson, D.A., Tannehill, J.C., and Pletcher, R.H., Computational Fluid Mechanics and Heat Transfer, Hemisphere Publishing Corporation, New York, 1984.

3. Cheatwood, F. M., DeJarnette, F.R., and Hamilton, H.H., II, "Geometrical Description for a Proposed Aeroassist Flight Experiment Vehicle," NASA TM-87714, July 1986.

4. Moss, J.N. and Price, J.M., "Survey of Blunt Body Flows Including Wakes at Hypersonic Low-Density Conditions," J. of Thermophysics and Heat Transfer 11(3) 321-329 (1997).

5. Moss, J.N., Mitcheltree, R.A., Dogra, V.K., and Wilmoth, R.G., "Direct Simulation Monte Carlo and Navier-Stokes Simulations of Blunt Body Wale Flows," AIAA J. 32(7), 1399-1406 (1994).

6. Horvath, T.J. and Hannemann, K., "Blunt Body Near Wake Flow Field at Mach 10," ALAA Paper 97-0986, January 1997.

7. Roveda, R., Goldstein, D.B., and Varghese, P.L., "A Hybrid Euler/DSMC Approach to Unsteady Flows," Rarefied Gas Dynamics, Vol. 2, Proceedings of the $21^{\text {st }}$ Rarefied Gas Dynamics Conference, Edited by R. Brun, R. Campargue, R. Gatignol, and J.-C. Lengrand., 117-124 (1998).

8. Tartabini, P.V., Wilmoth, R.G., and Rault, D.F.G., "Direct Simulation Monte Carlo Calculation of a Jet Interaction Experiment," J. of Spacecraft and Rockets, 32(1) 75-83 (1995).

9. Lumpkin III, F.E., LeBeau, G.J., and Stuart P.E., "A CFD/DSMC Analysis of Plume and Plume Impingement during Shuttle/Mir Docking," AIAA-95-2034 (1995).

10. Wilmoth, R.G., Mitcheltree, R.A., Moss, J.N., "Zonally Decoupled Direct Simulation Monte Carlo Solutions of Hypersonic Blunt-Body Wake Flows," J. of Spacecraft and Rockets 31(6), 971-979 (1994).

11. Cheatwood, F.M. and Gnoffo, P.A., "User's Manual for the Langley Aerothermodynamic Upwind Relaxation Algorithm (LAURA)", NASA TM-4674, April 1996.

12. LeBeau, G.J., "A parallel implementation of the direct simulation Monte Carlo method," Comput. Methods Appl. Mech. Engrg., 174, 319-337 (1999). 
are similar to those given previously [4], i.e., the size of the wake vortex region increases as $\mathrm{Kn}_{\mathrm{L}}$ decreases and flow attachment does not coincide with maximum $\mathrm{C}_{\mathrm{p}}$ and $\mathrm{C}_{\mathrm{H}}$, thus giving some credence to the present method. In addition, the results show that in the wake region for the flow conditions of this study, non-equilibrium chemistry is present in the wake behind the blunt body and should be accounted for in the simulation.

\section{ACKNOWLEDGMENTS}

The help provided by Gerald LeBeau of NASA JSC and Richard Wilmoth of NASA LaRC in resolving DAC code issues is acknowledged. James Moss of NASA LaRC provided helpful insight into wake flows of blunt body configurations. Jean Oswald of O.N.E.R.A. is acknowledged for providing the volume grid for CFD and the IGES surface definition of the MSRO. Ramadus Prabhu of Lockheed Martin was instrumental in creating a triangulated surface grid from the IGES format using the GridTool software.

\section{REFERENCES}

1. Bird, G.A., Molecular Gas Dynamics and the Direct Simulation of Gas Flows, Oxford University Press, New York, 1994.

2. Anderson, D.A., Tannehill, J.C., and Pletcher, R.H., Computational Fluid Mechanics and Heat Transfer, Hemisphere Publishing Corporation, New York, 1984.

3. Cheatwood, F. M., DeJarnette, F.R., and Hamilton, H.H., II, "Geometrical Description for a Proposed Aeroassist Flight Experiment Vehicle," NASA TM-87714, July 1986.

4. Moss, J.N. and Price, J.M., "Survey of Blunt Body Flows Including Wakes at Hypersonic Low-Density Conditions," J. of Thermophysics and Heat Transfer 11(3) 321-329 (1997).

5. Moss, J.N., Mitcheltree, R.A., Dogra, V.K., and Wilmoth, R.G., "Direct Simulation Monte Carlo and Navier-Stokes Simulations of Blunt Body Wale Flows," AIAA J. 32(7), 1399-1406 (1994).

6. Horvath, T.J. and Hannemann, K., "Blunt Body Near Wake Flow Field at Mach 10," ALAA Paper 97-0986, January 1997.

7. Roveda, R., Goldstein, D.B., and Varghese, P.L., "A Hybrid Euler/DSMC Approach to Unsteady Flows," Rarefied Gas Dynamics, Vol. 2, Proceedings of the $21^{\text {st }}$ Rarefied Gas Dynamics Conference, Edited by R. Brun, R. Campargue, R. Gatignol, and J.-C. Lengrand., 117-124 (1998).

8. Tartabini, P.V., Wilmoth, R.G., and Rault, D.F.G., "Direct Simulation Monte Carlo Calculation of a Jet Interaction Experiment," J. of Spacecraft and Rockets, 32(1) 75-83 (1995).

9. Lumpkin III, F.E., LeBeau, G.J., and Stuart P.E., "A CFD/DSMC Analysis of Plume and Plume Impingement during Shuttle/Mir Docking," AIAA-95-2034 (1995).

10. Wilmoth, R.G., Mitcheltree, R.A., Moss, J.N., "Zonally Decoupled Direct Simulation Monte Carlo Solutions of Hypersonic Blunt-Body Wake Flows," J. of Spacecraft and Rockets 31(6), 971-979 (1994).

11. Cheatwood, F.M. and Gnoffo, P.A., "User's Manual for the Langley Aerothermodynamic Upwind Relaxation Algorithm (LAURA)", NASA TM-4674, April 1996.

12. LeBeau, G.J., "A parallel implementation of the direct simulation Monte Carlo method," Comput. Methods Appl. Mech. Engrg., 174, 319-337 (1999). 


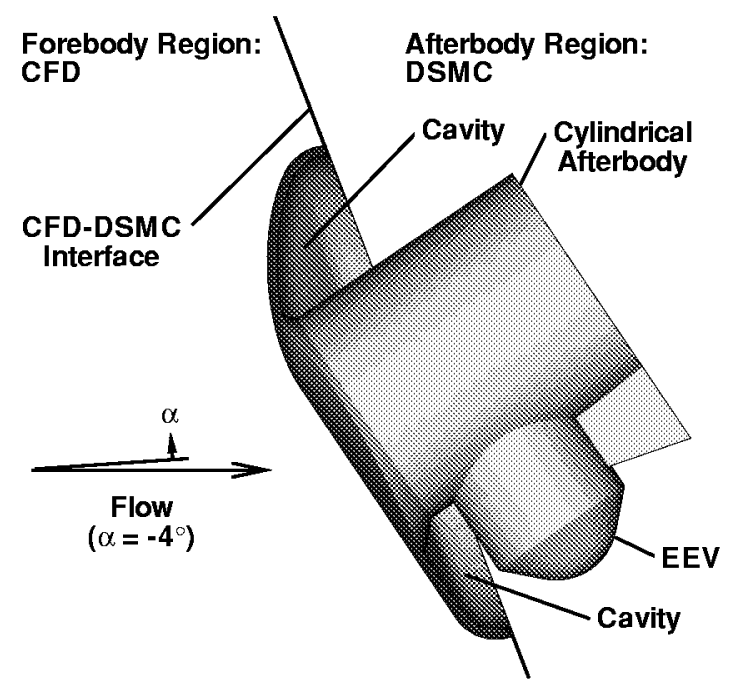

FIGURE 1. Side view of MSRO showing interface between CFD and DSMC domains.

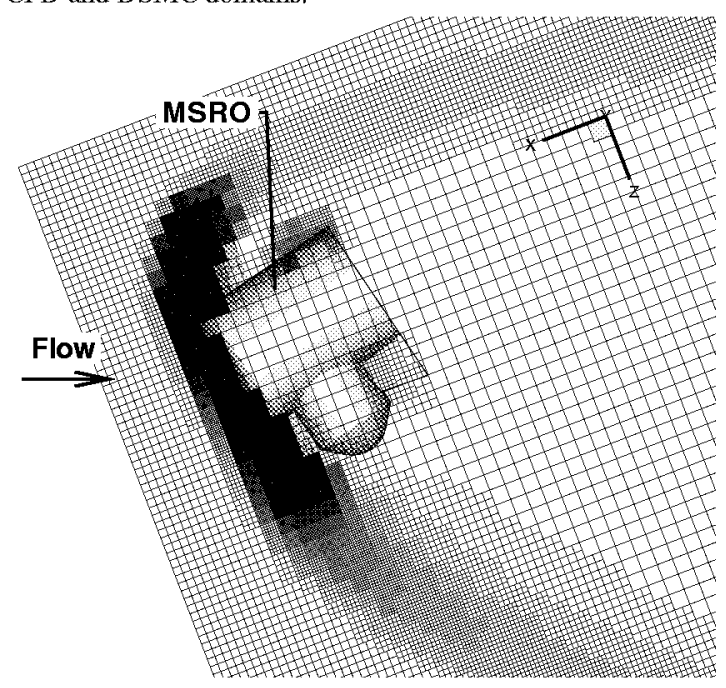

FIGURE 3. Fully adapted grid at symmetry plane for $\mathrm{Kn}_{\mathrm{L}}=0.02$.

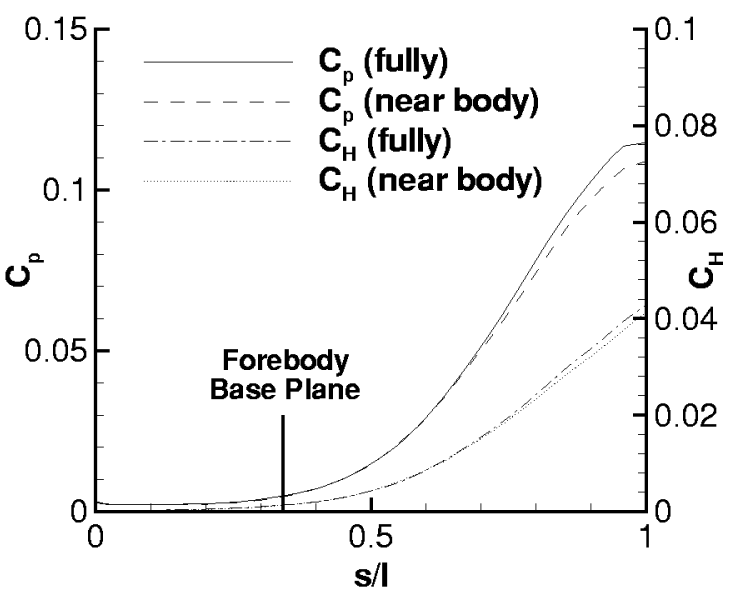

FIGURE 5. Comparison of $\mathrm{C}_{\mathrm{p}}$ and $\mathrm{C}_{\mathrm{H}}$ between fully and near body adapted grid solutions for $\mathrm{Kn}_{\mathrm{L}}=0.02$.

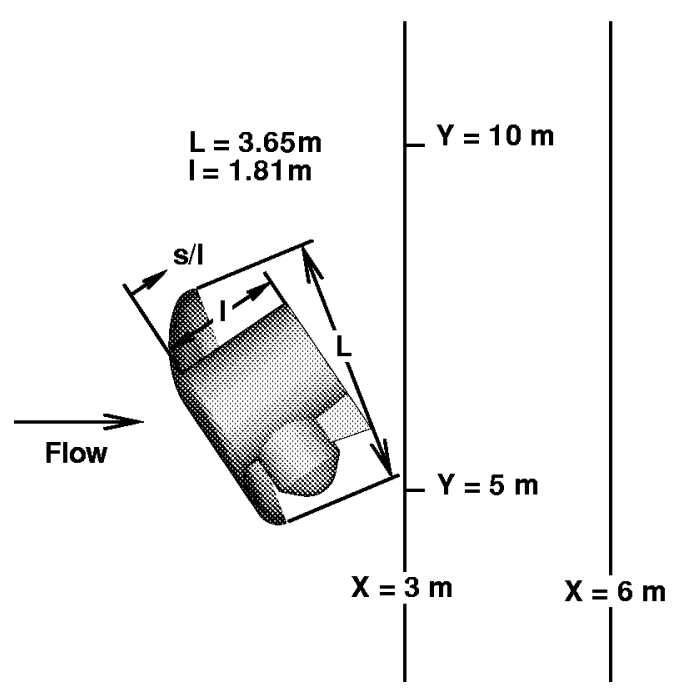

FIGURE 2. Key dimensions and locations where surface and flow field information are extracted from the symmetry plane.

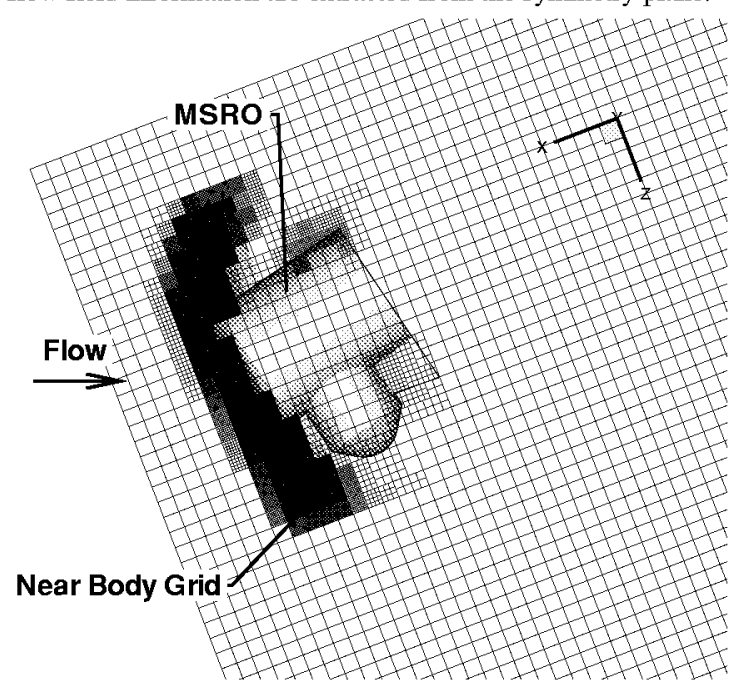

FIGURE 4 . Near body adapted grid at symmetry plane for $\mathrm{Kn}_{\mathrm{L}}=0.02$.

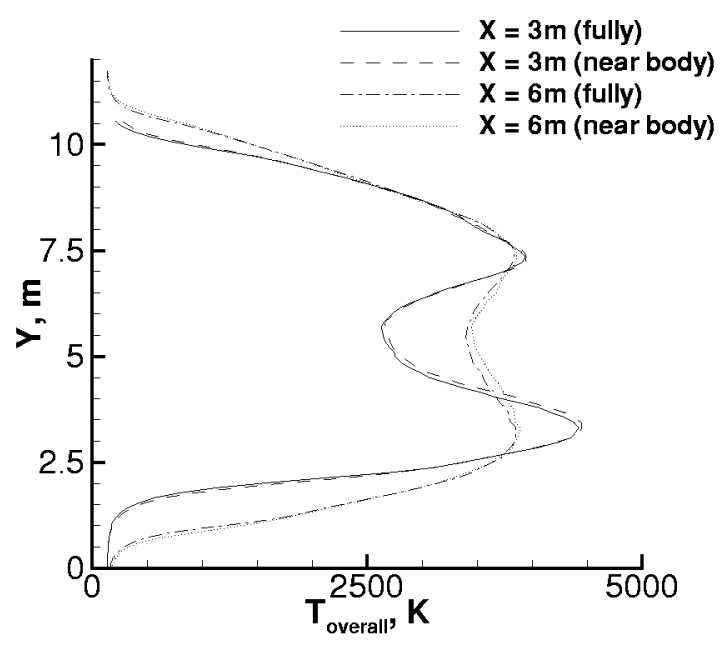

FIGURE 6. Temperature comparison between fully and near body adapted solutions for $\mathrm{Kn}_{\mathrm{L}}=0.02$. 


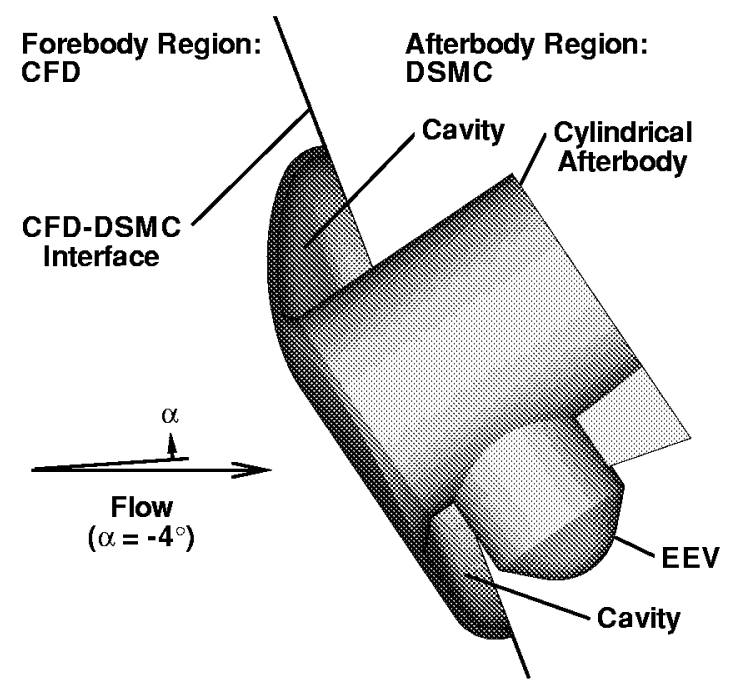

FIGURE 1. Side view of MSRO showing interface between CFD and DSMC domains.

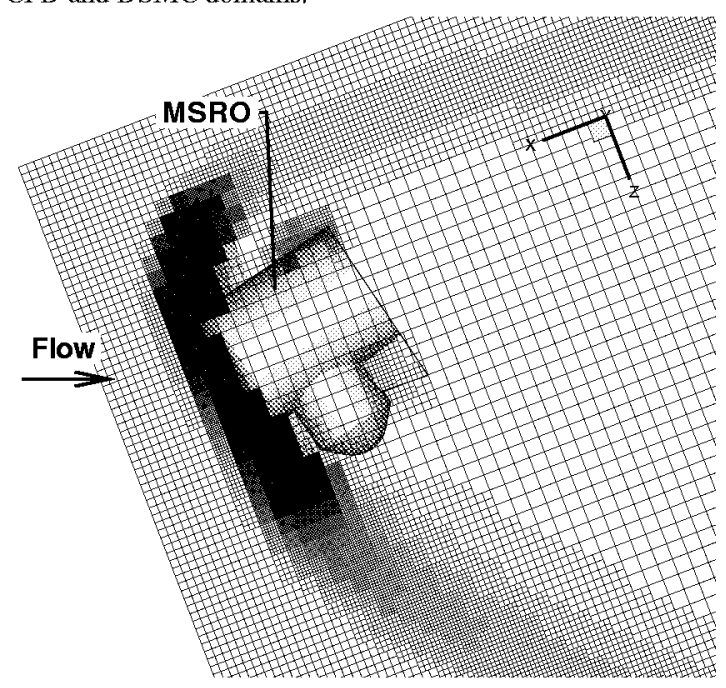

FIGURE 3. Fully adapted grid at symmetry plane for $\mathrm{Kn}_{\mathrm{L}}=0.02$.

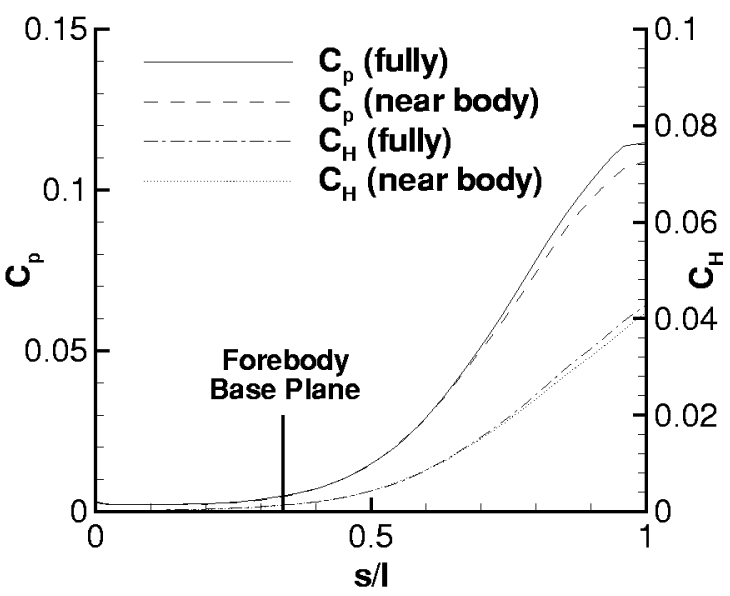

FIGURE 5. Comparison of $\mathrm{C}_{\mathrm{p}}$ and $\mathrm{C}_{\mathrm{H}}$ between fully and near body adapted grid solutions for $\mathrm{Kn}_{\mathrm{L}}=0.02$.

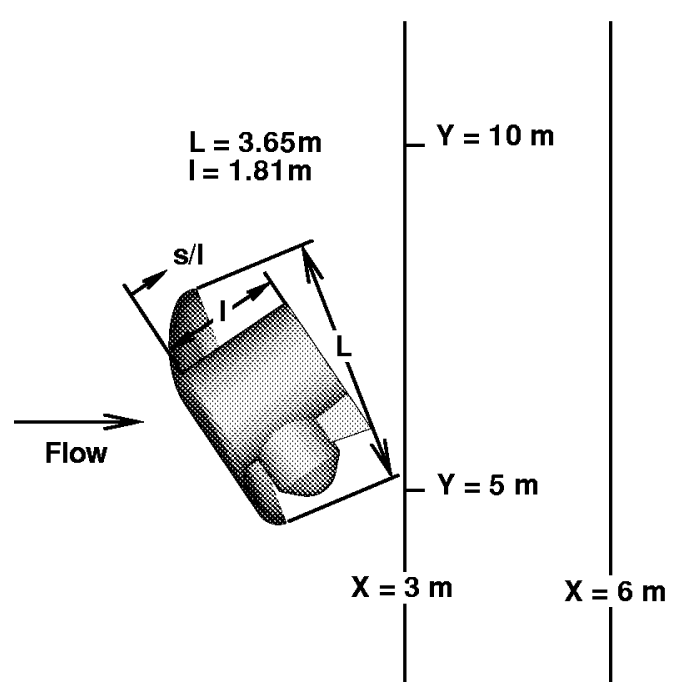

FIGURE 2. Key dimensions and locations where surface and flow field information are extracted from the symmetry plane.

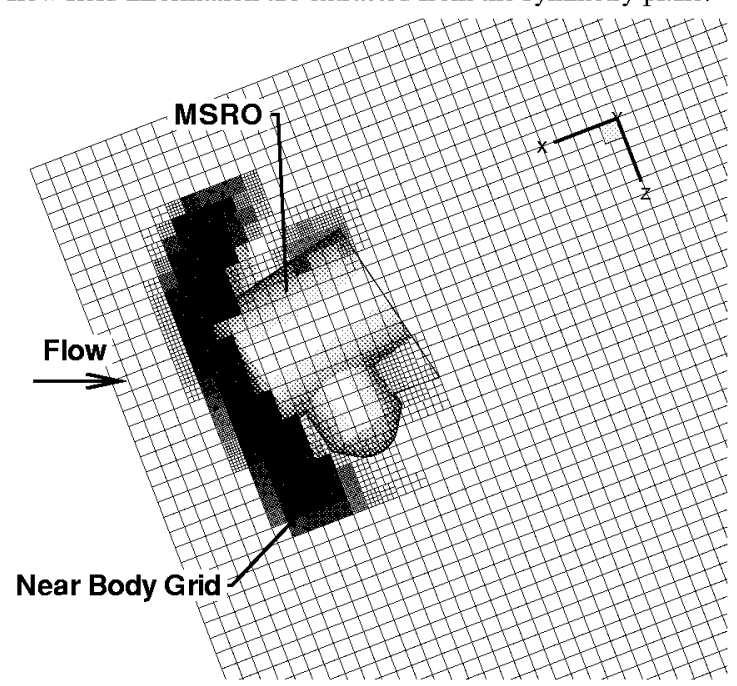

FIGURE 4 . Near body adapted grid at symmetry plane for $\mathrm{Kn}_{\mathrm{L}}=0.02$.

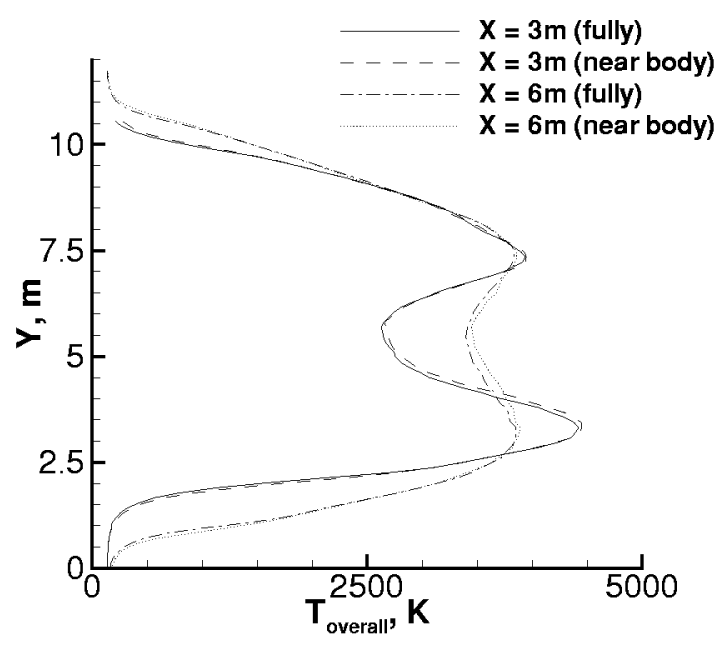

FIGURE 6. Temperature comparison between fully and near body adapted solutions for $\mathrm{Kn}_{\mathrm{L}}=0.02$. 


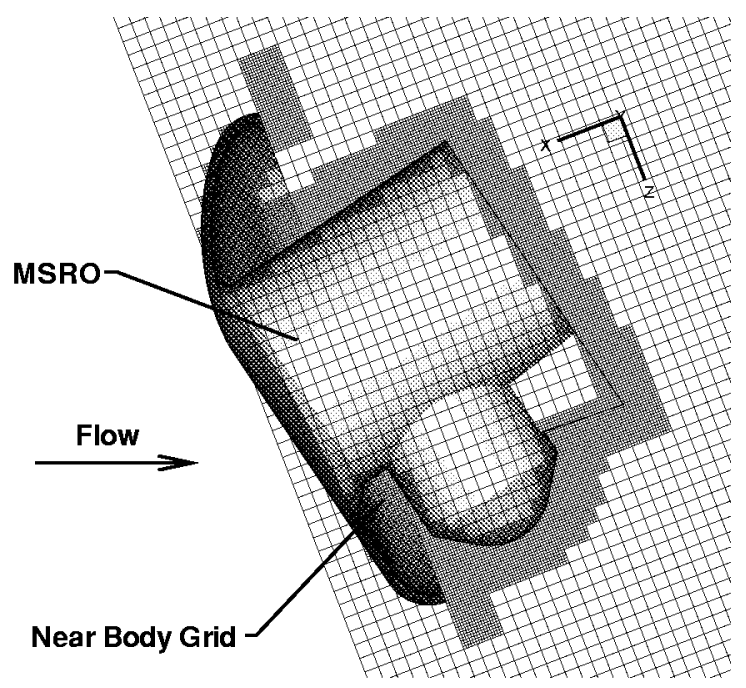

FIGURE 7. Adapted near body grid at symmetry plane for $\mathrm{Kn}_{\mathrm{L}}=0.002$.

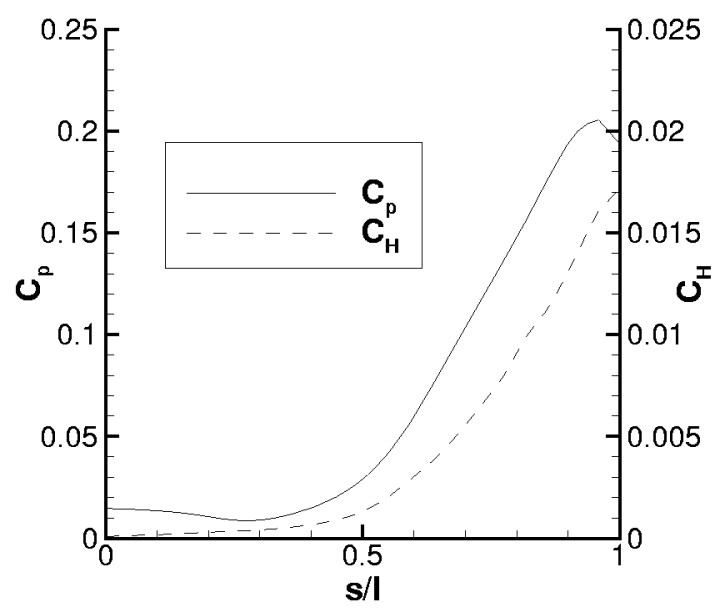

FIGURE 9. $\mathrm{C}_{\mathrm{P}}$ and $\mathrm{C}_{\mathrm{H}}$ on MSRO afterbody surface at symmetry plane for $\mathrm{Kn}_{\mathrm{L}}=0.002$.

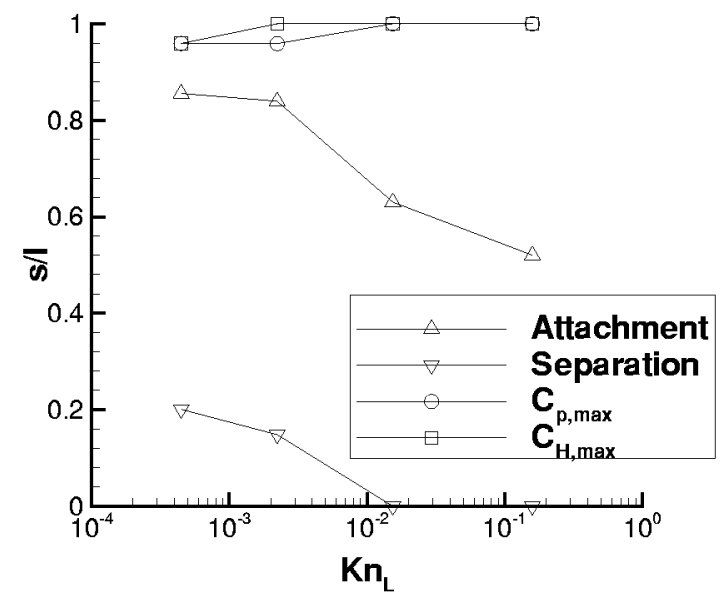

FIGURE 11. Location of attachment and separation, $\mathrm{C}_{\mathrm{p}, \max }$, and $\mathrm{C}_{\mathrm{H}, \max }$ on afterbody as a function of $\mathrm{Kn}_{\mathrm{L}}$.

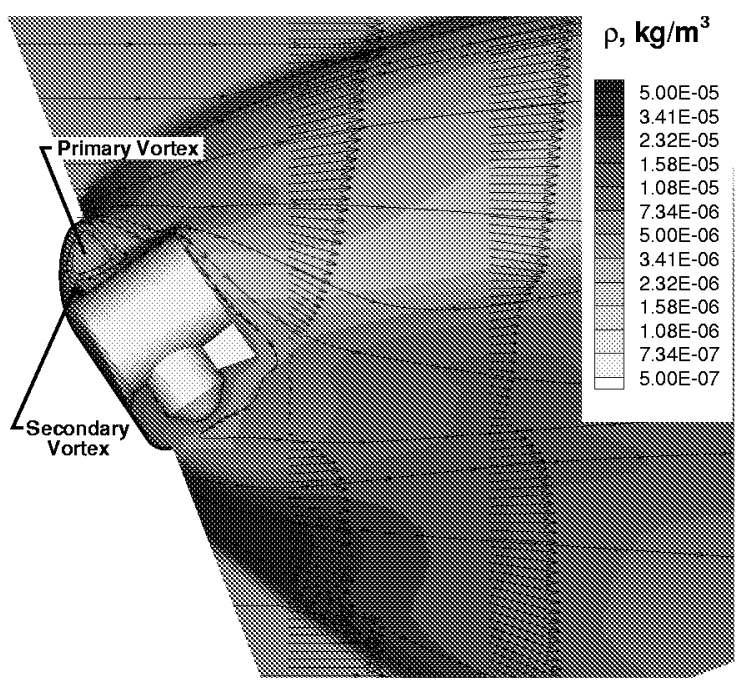

FIGURE 8 . Wake density profile, streamlines, and various velocity vectors on the symmetry plane for $\mathrm{Kn}_{\mathrm{L}}=0.002$.

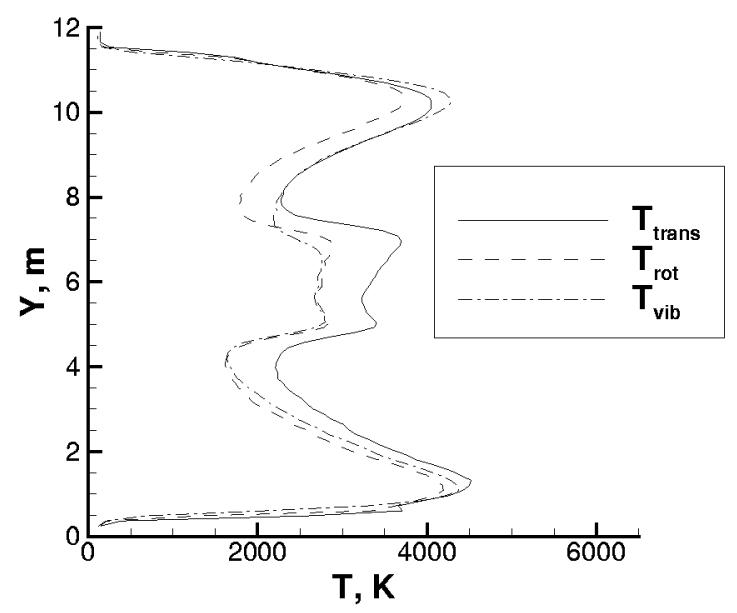

FIGURE 10. Comparison of MSRO flow field wake temperatures at $\mathrm{X}=6 \mathrm{~m}$ for $\mathrm{Kn}_{\mathrm{L}}=0.002$.

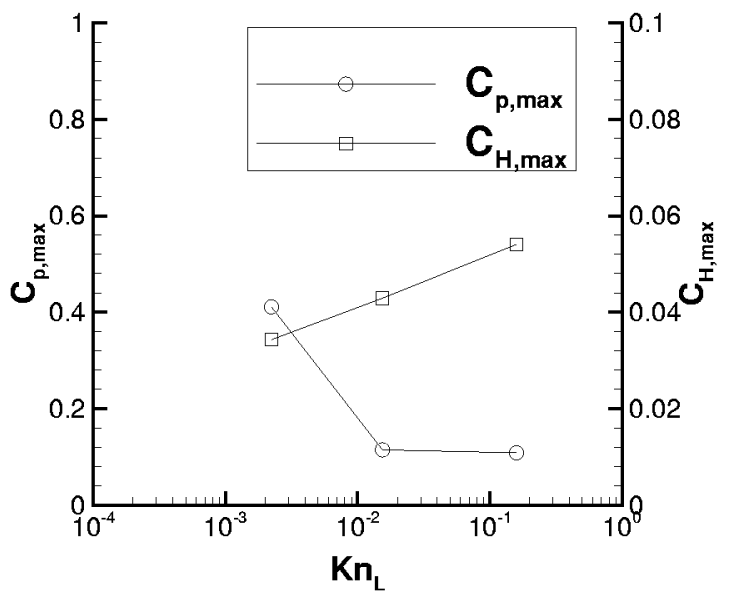

FIGURE 12. Magnitude of $\mathrm{C}_{\mathrm{p}, \max }$ and $\mathrm{C}_{\mathrm{H}, \max }$ as a function of $\mathrm{Kn}_{\mathrm{L}}$ 


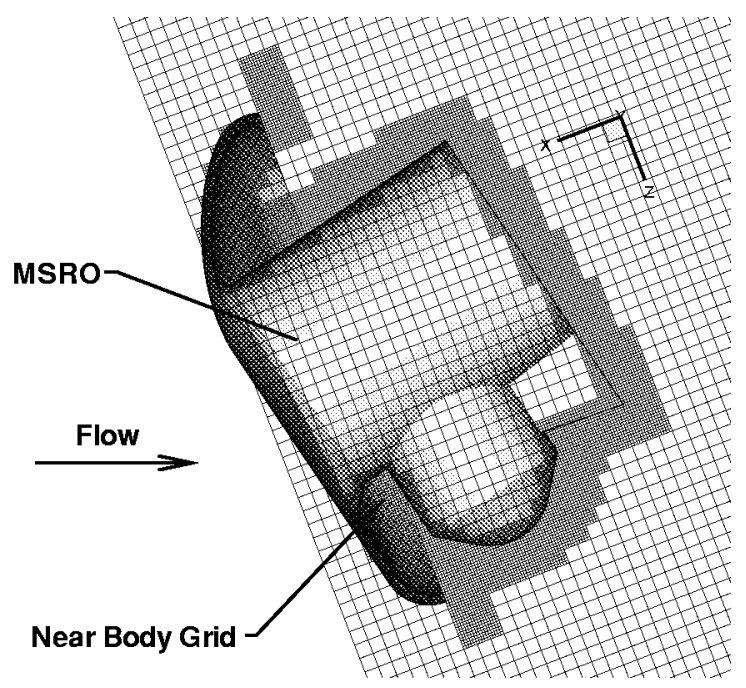

FIGURE 7. Adapted near body grid at symmetry plane for $\mathrm{Kn}_{\mathrm{L}}=0.002$.

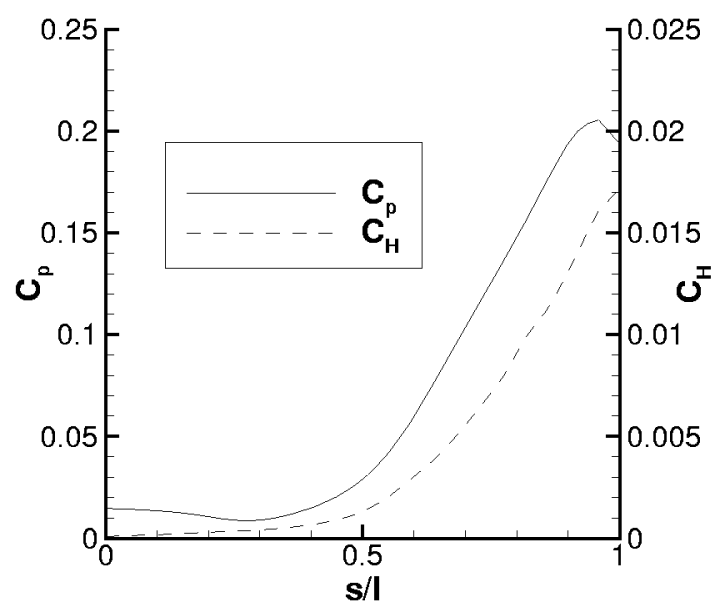

FIGURE 9. $\mathrm{C}_{\mathrm{P}}$ and $\mathrm{C}_{\mathrm{H}}$ on MSRO afterbody surface at symmetry plane for $\mathrm{Kn}_{\mathrm{L}}=0.002$.

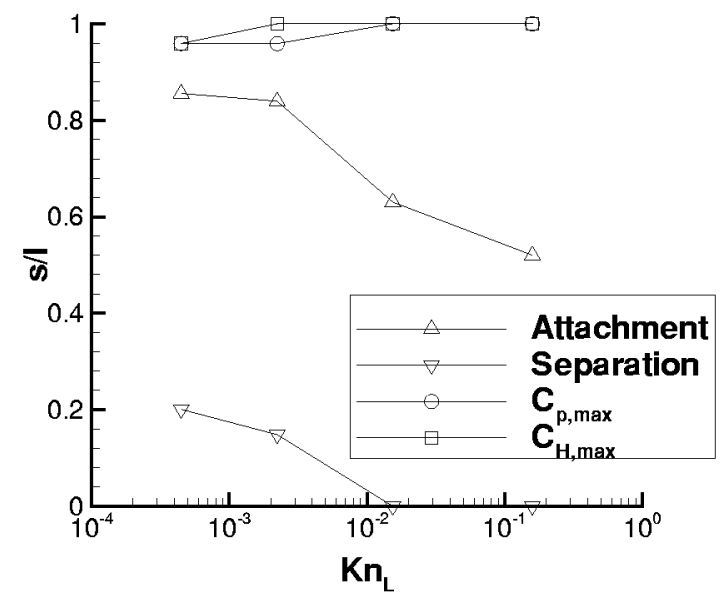

FIGURE 11. Location of attachment and separation, $\mathrm{C}_{\mathrm{p}, \max }$, and $\mathrm{C}_{\mathrm{H}, \max }$ on afterbody as a function of $\mathrm{Kn}_{\mathrm{L}}$.

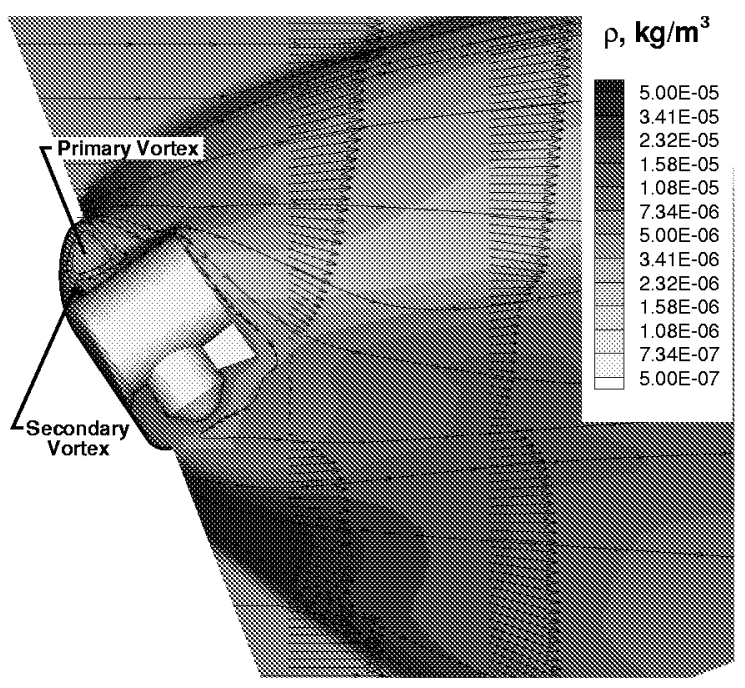

FIGURE 8 . Wake density profile, streamlines, and various velocity vectors on the symmetry plane for $\mathrm{Kn}_{\mathrm{L}}=0.002$.

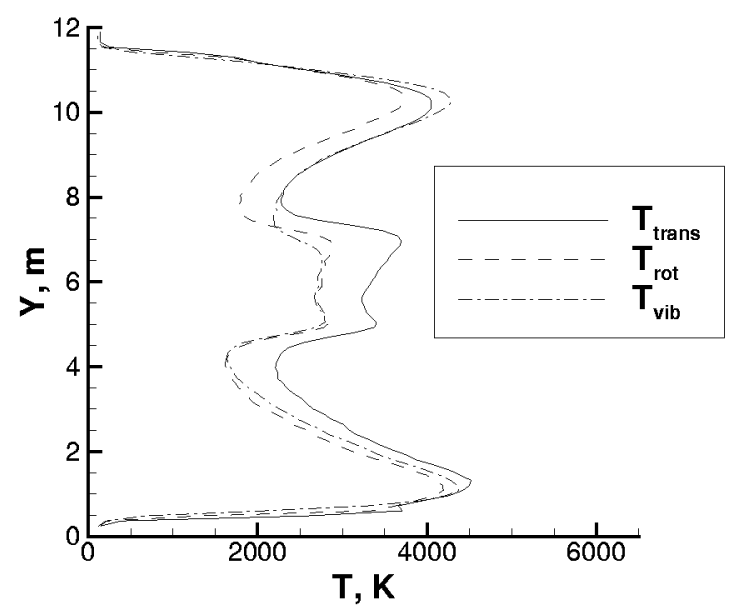

FIGURE 10. Comparison of MSRO flow field wake temperatures at $\mathrm{X}=6 \mathrm{~m}$ for $\mathrm{Kn}_{\mathrm{L}}=0.002$.

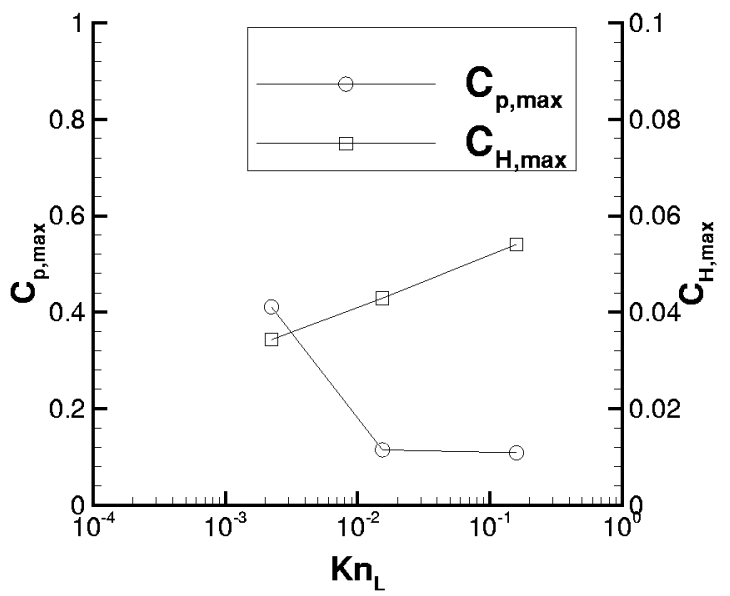

FIGURE 12. Magnitude of $\mathrm{C}_{\mathrm{p}, \max }$ and $\mathrm{C}_{\mathrm{H}, \max }$ as a function of $\mathrm{Kn}_{\mathrm{L}}$ 
Public reporting burden for this collection of information is estimated to average 1 hour per response, including the time for reviewing instructions, searching existing data sources, gathering and maintaining the data needed, and completing and reviewing the collection of information. Send comments regarding this burden estimate or any other aspect of this collection of information, including suggestions for reducing this burden, to Washington Headquarters Services, Directorate for Information Operations and

Reports, 1215 Jefferson Davis Highway, Suite 1204, Arlington, VA 22202-4302, and to the Office of Management and Budget, Paperwork Reduction Project (0704-0188), Washington, DC 20503.

\begin{tabular}{|l|l|l|}
\hline 1. AGENCY USE ONLY (Leave blank) & $\begin{array}{l}\text { 2. REPORT DATE } \\
\text { July } 2000\end{array}$ & $\begin{array}{l}\text { 3. REPORT TYPE AND DATES COVERED } \\
\text { Technical Memorandum }\end{array}$ \\
\hline
\end{tabular}

\begin{tabular}{l|l|l} 
4. TITLE AND SUBTITLE & 5. FUNDING NUMBERS
\end{tabular}

A 3-D Coupled CFD-DSMC Solution Method With Application to the

WU 242-80-01-01

Mars Sample Return Orbiter

6. AUTHOR(S)

Christopher E. Glass and Peter A. Gnoffo

7. PERFORMING ORGANIZATION NAME(S) AND ADDRESS(ES)

8. PERFORMING ORGANIZATION REPORT NUMBER

NASA Langley Research Center

Hampton, VA 23681-2199

L-18012

9. SPONSORING/MONITORING AGENCY NAME(S) AND ADDRESS(ES)

10. SPONSORING/MONITORING AGENCY REPORT NUMBER

National Aeronautics and Space Administration

Washington, DC 20546-0001

NASA/TM-2000-210322

\section{SUPPLEMENTARY NOTES}

Presented at the $22^{\text {nd }}$ International Symposium on Rarefied Gas Dynamics, Sydney, Australia, July 2000.

12a. DISTRIBUTION/AVAILABILITY STATEMENT

12b. DISTRIBUTION CODE

Unclassified-Unlimited

Subject Category 34 Distribution: Nonstandard

Availability: NASA CASI (301) 621-0390

13. ABSTRACT (Maximum 200 words)

A method to obtain coupled CFD-DSMC, 3-D flow field solutions for highly blunt bodies at low incidence is presented and applied to one concept of the Mars Sample Return Orbiter vehicle as a demonstration of the technique. CFD is used to solve the high-density blunt forebody flow defining an inflow boundary condition for a DSMC solution of the afterbody wake flow. By combining the two techniques in flow regions where most applicable, the entire mixed flow field is modeled in an appropriate manner.

\section{SUBJECT TERMS}

Aerobraking; Blunt body wake; Coupled CFD-DSMC; Direct simulation Monte Carlo; Mars Sample Return Orbiter (MSRO); Rarefied flow

\begin{tabular}{l|c|c|}
\hline $\begin{array}{l}\text { 17. SECURITY CLASSIFICATION } \\
\text { OF REPORT } \\
\text { Unclassified }\end{array}$ & $\begin{array}{c}\text { 18. SECURITY CLASSIFICATION } \\
\text { OF THIS PAGE } \\
\text { Unclassified }\end{array}$ & $\begin{array}{c}\text { 19. SECURITY CLASSIFICATION } \\
\text { OF ABSTRACT } \\
\text { Unclassified }\end{array}$ \\
\hline
\end{tabular}

15. NUMBER OF PAGES 12

16. PRICE CODE A03

20. LIMITATION OF ABSTRACT

UL 
Public reporting burden for this collection of information is estimated to average 1 hour per response, including the time for reviewing instructions, searching existing data sources, gathering and maintaining the data needed, and completing and reviewing the collection of information. Send comments regarding this burden estimate or any other aspect of this collection of information, including suggestions for reducing this burden, to Washington Headquarters Services, Directorate for Information Operations and

Reports, 1215 Jefferson Davis Highway, Suite 1204, Arlington, VA 22202-4302, and to the Office of Management and Budget, Paperwork Reduction Project (0704-0188), Washington, DC 20503.

\begin{tabular}{|l|l|l|}
\hline 1. AGENCY USE ONLY (Leave blank) & $\begin{array}{l}\text { 2. REPORT DATE } \\
\text { July } 2000\end{array}$ & $\begin{array}{l}\text { 3. REPORT TYPE AND DATES COVERED } \\
\text { Technical Memorandum }\end{array}$ \\
\hline
\end{tabular}

\begin{tabular}{l|l|l} 
4. TITLE AND SUBTITLE & 5. FUNDING NUMBERS
\end{tabular}

A 3-D Coupled CFD-DSMC Solution Method With Application to the

WU 242-80-01-01

Mars Sample Return Orbiter

6. AUTHOR(S)

Christopher E. Glass and Peter A. Gnoffo

7. PERFORMING ORGANIZATION NAME(S) AND ADDRESS(ES)

8. PERFORMING ORGANIZATION REPORT NUMBER

NASA Langley Research Center

Hampton, VA 23681-2199

L-18012

9. SPONSORING/MONITORING AGENCY NAME(S) AND ADDRESS(ES)

10. SPONSORING/MONITORING AGENCY REPORT NUMBER

National Aeronautics and Space Administration

Washington, DC 20546-0001

NASA/TM-2000-210322

\section{SUPPLEMENTARY NOTES}

Presented at the $22^{\text {nd }}$ International Symposium on Rarefied Gas Dynamics, Sydney, Australia, July 2000.

12a. DISTRIBUTION/AVAILABILITY STATEMENT

12b. DISTRIBUTION CODE

Unclassified-Unlimited

Subject Category 34 Distribution: Nonstandard

Availability: NASA CASI (301) 621-0390

13. ABSTRACT (Maximum 200 words)

A method to obtain coupled CFD-DSMC, 3-D flow field solutions for highly blunt bodies at low incidence is presented and applied to one concept of the Mars Sample Return Orbiter vehicle as a demonstration of the technique. CFD is used to solve the high-density blunt forebody flow defining an inflow boundary condition for a DSMC solution of the afterbody wake flow. By combining the two techniques in flow regions where most applicable, the entire mixed flow field is modeled in an appropriate manner.

\section{SUBJECT TERMS}

Aerobraking; Blunt body wake; Coupled CFD-DSMC; Direct simulation Monte Carlo; Mars Sample Return Orbiter (MSRO); Rarefied flow

\begin{tabular}{l|c|c|}
\hline $\begin{array}{l}\text { 17. SECURITY CLASSIFICATION } \\
\text { OF REPORT } \\
\text { Unclassified }\end{array}$ & $\begin{array}{c}\text { 18. SECURITY CLASSIFICATION } \\
\text { OF THIS PAGE } \\
\text { Unclassified }\end{array}$ & $\begin{array}{c}\text { 19. SECURITY CLASSIFICATION } \\
\text { OF ABSTRACT } \\
\text { Unclassified }\end{array}$ \\
\hline
\end{tabular}

15. NUMBER OF PAGES 12

16. PRICE CODE A03

20. LIMITATION OF ABSTRACT

UL 